\title{
SHARP POWER MEAN BOUNDS FOR THE
}

\section{TANGENT AND HYPERBOLIC SINE MEANS}

\section{Tie-Hong ZhaO, Wei-Mao Qian And Yu-Ming ChU*}

Abstract. In the article, we prove that the double inequalities

$$
\begin{aligned}
& \boldsymbol{M}_{\alpha_{1}}(a, b)<\boldsymbol{M}_{\tan }(a, b)<\boldsymbol{M}_{\beta_{1}}(a, b), \\
& \boldsymbol{M}_{\alpha_{2}}(a, b)<\boldsymbol{M}_{\sinh }(a, b)<\boldsymbol{M}_{\beta_{2}}(a, b)
\end{aligned}
$$

hold for all $a, b>0$ with $a \neq b$ if and only if $\alpha_{1} \leqslant 1 / 3, \beta_{1} \geqslant \log 2 / \log (2 \tan 1) \approx 0.61007$, $\alpha_{2} \leqslant 2 / 3$ and $\beta_{2} \geqslant \log 2 / \log (2 \sinh 1) \approx 0.81109$, where $\boldsymbol{M}_{p}, \boldsymbol{M}_{\text {tan }}$ and $\boldsymbol{M}_{\text {sinh }}$ are the $p^{\text {th }}$ power mean, tangent mean and hyperbolic sine mean, respectively.

Mathematics subject classification (2020): 26D15.

Keywords and phrases: Power mean, hyperbolic sine mean, tangent mean, Seiffert function.

\section{REFERENCES}

[1] M. Abramowitz And I. A. Stegun, Handbook of Mathematical Functions with Formulas, Graphs, and Mathematical Tables, National Bureau of Standards, Applied Mathematics Series 55, 9th printing, Washington, (1970).

[2] P. A. HÄstö, Optimal inequalities between Seiffert mean and power means, Math. Inequal. Appl., 7, 1 (2004), 47-53.

[3] L. Li, W.-K. WANG, L.-H. HuAng AND J.-H. WU, Some weak flocking models and its application to target tracking, J. Math. Anal. Appl., 480, 2 (2019), Art. ID 123404, 22 pages.

[4] T.-P. Lin, The power mean and the logarithmic mean, Am. Math. Mon., 81, 2 (1974), 879-883.

[5] Y.-M. LI, M.-K. WANG AND Y.-M. CHU, Sharp power mean bounds for Seiffert mean, Appl. Math. J. Chin. Univ., 29B, 1 (2014), 101-107.

[6] T.-H. ZhaO, W.-M. QIAN AND Y.-M. ChU, On approximating the arc lemniscate functions, Indian J. Pure Appl. Math., (2021), https://doi.org/10.1007/s13226-021-00016-9.

[7] E. Neuman And J. SÁndor, On the Schwab-Borchardt mean, Math. Pannon., 14, 2 (2003), 253 266.

[8] E. Neuman And J. SÁndor, On the Schwab-Borchardt mean II, Math. Pannon., 17, 1 (2006), 4959.

[9] M. NowickA AND A. WitkowsKi, Optimal bounds for the tangent and hyperbolic sine means, Aequat. Math., 94, 5 (2020), 817-827.

[10] M. NowICKA AND A. WITKOWSKI, Optimal bounds for the tangent and hyperbolic sine means II, J. Math. Inequal., 14, 1 (2020), 23-33.

[11] T.-H. ZHAO, Z.-Y. HE AND Y.-M. CHU, Sharp bounds for the weighted Hölder mean of the zerobalanced generalized complete elliptic integrals, Comput. Methods Funct. Theory, 21, 3 (2021), $413-$ 426.

[12] F. QI, A double inequality for the ratio of two non-zero neighbouring Bernoulli numbers, J. Comput. Appl. Math. 351, (2019), 1-5.

[13] S.-L. QIU, Y.-F. QIU, M.-K. WANG AND Y.-M. CHU, Hölder mean inequalities for the generalized Grötzsch ring and Hersch-Pfluger distortion function, Math. Inequal. Appl., 15, 1 (2012), 237-245.

[14] T.-H. ZHAO, B. A. BHAYO AND Y.-M. CHU, Inequalities for generalized Grötzsch ring function, Comput. Methods Funct. Theory, (2021), https://doi .org/10.1007/s40315-021-00415-3. 
[15] K. B. Stolarsky, Hölder means, Lehmer means, and $x^{-1} \log \cosh x$, J. Math. Anal. Appl., 202, 3 (1996), 810-818.

[16] M.-K. WAng, H.-H. ChU And Y.-M. CHU, Precise bounds for the weighted Hölder mean of the complete p-elliptic integrals, J. Math. Anal. Appl., 48, 2 (2019), 123388.

[17] M.-K. WANG, Y.-M. CHU, S.-L. QIU AND Y.-P. JIANG, Convexity of the complete elliptic integrals of the first kind with respect to Hölder means, J. Math. Anal. Appl., 388, 2 (2012), 1141-1146.

[18] M.-K. WAng, Y.-M. CHU, Y.-F. QIU AND S.-L. QIU, An optimal power mean inequality for the complete elliptic integrals, Appl. Math. Lett., 24, 6 (2011), 887-890.

[19] A. Witkows Ki, On Seiffert-like means, J. Math. Inequal., 4, 9 (2015), 1071-1092.

[20] G.-D. WANG, X.-H. ZHANG AND Y.-M. CHU, A power mean inequality for the Grötzsch ring function, Math. Inequal. Appl., 14, 4 (2011), 833-837.

[21] G.-D. WAng, X.-H. Zhang AND Y.-M. CHU, A power mean inequality involving the complete elliptic integrals, Rocky Mt. J. Math., 44, 5 (2014), 1661-1667.

[22] Z.-H. YANG, Estimates for Neuman-Sándor mean by power means and their relative errors, J. Math. Inequal., 7, 4 (2013), 711-726.

[23] Z.-H. YANG, Y.-M. CHU AND X.-J, TAO, A double inequality for the trigamma function and its applications, Abstr. Appl. Anal., Art. ID 702718, (2014), 9 pages.

[24] H.-Z. XU, W.-M. QIAN AND Y.-M. CHU, Sharp bounds for the lemniscatic mean by the oneparameter geometric and quadratic means, Rev. R. Acad. Cienc. Exactas Fís. Nat. Ser. A Mat. RACSAM, 116, 1 (2022), Paper No. 21, 15 pages.

[25] T.-H.ZHAO, Z.-H. SHEN AND Y.-M. CHU, Sharp power mean bounds for the lemniscate type means, Rev. R. Acad. Cienc. Exactas Fís. Nat. Ser. A Mat. RACSAM, 115, 4 (2021), Paper No. 175, 16 pages.

[26] Z.-H. YANG, W.-M. QIAN, Y.-M. CHU AND W. ZHANG, On rational bounds for the gamma function, J. Inequal. Appl., 2017, Paper No. 210 (2017), 17 pages.

[27] T.-H. ZHAO, L. SHI AND Y.-M. CHU, Convexity and concavity of the modified Bessel functions of the first kind with respect to Hölder means, Rev. R. Acad. Cienc. Exactas Fís. Nat. Ser. A Mat. RACSAM., 114, 2 (2020), Article 96. 